\title{
Postoperative recurrence and the role of adjuvant chemotherapy in patients with pulmonary large-cell neuroendocrine carcinoma
}

\author{
Akira Iyoda, MD, PhD, ${ }^{\mathrm{a}}$ Kenzo Hiroshima, $\mathrm{MD}, \mathrm{PhD},{ }^{\mathrm{b}}$ Yasumitsu Moriya, MD, $\mathrm{PhD},{ }^{\mathrm{a}}$ Yasuo Iwadate, MD, \\ $\mathrm{PhD},{ }^{\mathrm{c}}$ Yuichi Takiguchi, MD, PhD, ${ }^{\mathrm{d}}$ Takashi Uno, MD, PhD, ${ }^{\mathrm{e}}$ Yukio Nakatani, MD, PhD, ${ }^{\mathrm{b}}$ and \\ Ichiro Yoshino, $\mathrm{MD}, \mathrm{PhD}^{\mathrm{a}}$
}

\begin{abstract}
Objectives: The prognosis for patients with large-cell neuroendocrine carcinoma is generally very poor. In this study, we describe the clinical features of recurrent tumors of large-cell neuroendocrine carcinoma and discuss the role of adjuvant chemotherapy and management of recurrence in patients with large-cell neuroendocrine carcinoma.
\end{abstract}

\begin{abstract}
Methods: We retrospectively analyzed clinical data from 79 patients and evaluated the prognosis of patients with platinum-based adjuvant chemotherapy, recurrence patterns, patient response to chemotherapy or radiation therapy, and prognosis in patients who experienced relapse.

Results: Of 72 patients, 36 had confirmed recurrent tumors upon follow-up examinations. Of those with recurrent tumors, 33 patients $(91.7 \%$ ) had their first recurrent tumors within 3 years. Patients who underwent platinumbased adjuvant chemotherapy had a significantly lower rate of tumor recurrence and a higher rate of diseasefree survival than those who had non-platinum-based adjuvant chemotherapy or no adjuvant chemotherapy. Multivariate analyses revealed that platinum-based adjuvant chemotherapy, pathologic stage, and the presence of second cancer are independent prognostic factors. Three patients with limited resection of the primary tumor had poor prognosis with recurrence. Postoperatively, 11 of the 36 patients without recurrence $(30.6 \%)$ had metachronous second primary cancers, of which 4 patients had more than 1 site.
\end{abstract}

Conclusions: Patients with large-cell neuroendocrine carcinoma had frequent recurrence following resection of the primary tumor, and those without recurrence often developed metachronous second primary cancers. Platinum-based adjuvant chemotherapy after surgery may be useful for preventing recurrence in patients with large-cell neuroendocrine carcinoma.

It has been found that the biologic behavior of large-cell neuroendocrine carcinoma (LCNEC) tumors resembles that of small-cell lung carcinomas, that LCNECs show features of high-grade neuroendocrine tumors, and that LCNECs are aggressive tumors and patients with LCNEC have very poor prognoses. ${ }^{1-9}$ Based on the following studies, the efficacy of adjuvant chemotherapy should be examined for patients with LCNEC. ${ }^{10-12}$ Iyoda and colleagues ${ }^{12}$ performed a prospective study beginning in 2000 on the use of adjuvant chemotherapy for patients with LCNEC. They selected cisplatin + etoposide for their chemotherapeutic regimen, which is similar to that used for small-cell lung carcinoma

From the Departments of Thoracic Surgery, ${ }^{a}$ Diagnostic Pathology, ${ }^{\mathrm{b}}$ Neurological Surgery, ${ }^{\mathrm{c}}$ Respirology, ${ }^{\mathrm{d}}$ and Radiology, ${ }^{\mathrm{e}}$ Graduate School of Medicine, Chiba University, Chiba, Japan.

This work was supported in part by a Grant-in-aid for Scientific research (C) 17591458 and 19591610 of the Japanese Ministry of Education, Culture, Sports, Science, and Technology

Received for publication March 5, 2008; revisions received Dec 9, 2008; accepted for publication Dec 27, 2008; available ahead of print March 27, 2009

Address for reprints: Akira Iyoda, MD, PhD, Department of Thoracic Surgery, Graduate School of Medicine, Chiba University, 1-8-1, Inohana, Chuo-ku, Chiba 260-8670, Japan (E-mail: aiyoda@med.kitasato-u.ac.jp).

J Thorac Cardiovasc Surg 2009;138:446-53

0022-5223/\$36.00

Copyright $(\odot 2009$ by The American Association for Thoracic Surgery doi:10.1016/j.jtcvs.2008.12.037 as the clinicopathologic and biologic features of LCNEC are very similar. Their results showed good prognosis for patients with adjuvant chemotherapy based on cisplatin + etoposide after complete surgical resection. Rossi and colleagues ${ }^{13}$ also reported that adjuvant chemotherapy based on cisplatin + etoposide was effective for patients with LCNEC in a retrospective study. Thus, adjuvant chemotherapy following complete resection of LCNEC tumors appears promising for improving prognosis. However, little is known regarding recurrence of LCNEC tumors. Identification of frequent sites of recurrence and an understanding of the role of adjuvant chemotherapy are necessary for planning treatment of patients with LCNEC who have had surgery as an initial treatment. In this study, we describe the clinical features of recurrent tumors of LCNEC and discuss the role of adjuvant chemotherapy and management of recurrence in patients with LCNEC.

\section{PATIENTS AND METHODS}

We retrospectively analyzed clinical data from 79 patients with primary lung carcinoma diagnosed as LCNEC who underwent treatment at Chiba University Hospital. In resected specimens after surgery, LCNEC was diagnosed if there were both evidence of neuroendocrine differentiation detected by immunohistochemistry or electron microscopy and the following neuroendocrine morphologic features: (1) neuroendocrine morphology such as 


\section{Abbreviations and Acronyms}

$\mathrm{CT}=$ computed tomography

LCNEC $=$ large-cell neuroendocrine carcinoma

organoid nesting, palisading, rosettes, and trabeculae; (2) a high mitotic rate of at least 11 per $2 \mathrm{~mm}^{2}$ (10 high-power fields); (3) necrosis (often large zone); (4) cytologic features of a non-small cell carcinoma including large cell size, low nuclear-to-cytoplasm volume ratio, vesicular or fine chromatin, and/or frequent nucleoli. Immunohistochemical staining was done using a polyclonal anti-chromogranin A antibody (Nichirei Corporation, Tokyo, Japan), a monoclonal anti-synaptophysin antibody (DAKO, Glostrup, Denmark), and an anti-neural cell adhesion molecule (NCAM) antibody (Zymed, South San Francisco, Calif). Neuroendocrine differentiation was identified by positive immunohistochemical staining for chromogranin A, synaptophysin, or NCAM. ${ }^{1,12}$

The following parameters were investigated from the medical records: patient gender, age, smoking index, tumor size, tumor location, surgical procedure, pathologic TNM stage, adjuvant chemotherapy, time of recurrence, site of recurrence, response to treatment, and patient outcome.

\section{Treatments and Evaluation}

We evaluated the response of LCNEC recurrent tumors based on Response Evaluation Criteria in Solid Tumors Guidelines. ${ }^{14}$ We performed routine follow-ups of patients with LCNEC 3 or 4 times per year, checking symptoms and chest roentgenography. We also performed chest computed tomography $(\mathrm{CT})$ at least one time per year. If abnormal findings were observed, we used CT to evaluate the hilar-mediastinal and extrathoracic lymph nodes, the lung field, and the abdomen, and we used magnetic resonance imaging or CT to evaluate brain lesions. Bone scintigraphy was used to evaluate bone metastases. In some patients, we used positron emission tomography scans to detect postoperative distant metastases. If recurrent tumors were suspected, other sites were also examined.

Because this was a retrospective study, the treatment was not unified, especially treatment of recurrent tumors. However, a prospective study on the use of adjuvant chemotherapy was begun in 2000, and patients with LCNEC have been evaluated on the efficacy of adjuvant chemotherapy using cisplatin + etoposide following surgery, except for those patients without inclusion criteria. ${ }^{12}$

The Institutional Review Board of Chiba University Hospital approved protocols and procedures.

\section{Statistical Analysis}

Fisher exact test was used to compare binomial proportions. The Wilcoxon test and $\chi^{2}$ test were used to assess differences in treatment. Survival time was calculated from the date of surgery until the time of recurrence or death or date of last follow-up and was evaluated using the method of Kaplan and Meier. Curves obtained were compared using the log-rank test. The prognostic impact of the following clinical variables was investigated using Cox proportional hazards multivariable regression model and propensity score analysis: platinum-based adjuvant chemotherapy ( - vs + ), gender (male vs female), age ( $<65$ years vs $\geq 65$ years), pathologic stage (Ia or Ib vs IIa, IIb, IIIa, IIIb, or IV). Surgery (standard operation vs limited resection), postoperative complication (-vs +), and second cancer (-vs +). In propensity score analysis, we made a propensity score for the factor of platinum-based adjuvant chemotherapy, selected matching cases for propensity score, and compared the prognosis of patients with platinum-based adjuvant chemotherapy with the prognosis of patients without those

\section{RESULTS}

All patients had surgical resections of their primary tumors, which were then histologically determined to be

TABLE 1. Characteristics of 72 informative patients with large-cell neuroendocrine carcinoma between group with platinum-based adjuvant chemotherapy and group without

\begin{tabular}{|c|c|c|c|c|}
\hline \multirow[b]{2}{*}{ Factor } & \multirow[b]{2}{*}{ Category } & \multicolumn{2}{|c|}{ Adjuvant chemotherapy } & \multirow[b]{2}{*}{$P$ value } \\
\hline & & + & - & \\
\hline Number & & $30(100.0 \%)$ & $42(100.0 \%)$ & \\
\hline \multirow[t]{2}{*}{ Age (y) } & Mean & 63.2 & 65.8 & .326 (Wilcoxon) \\
\hline & Standard deviation & 9.6 & 7.7 & \\
\hline \multirow[t]{2}{*}{ Gender } & Male & $30(100.0 \%)$ & $36(85.7 \%)$ & .037 (Fisher) \\
\hline & Female & $0(0.0 \%)$ & $6(14.3 \%)$ & \\
\hline \multirow[t]{7}{*}{ Pathologic stage } & Ia & $8(26.7 \%)$ & $12(28.6 \%)$ & .898 (Wilcoxon) \\
\hline & $\mathrm{Ib}$ & $6(20.0 \%)$ & $9(21.4 \%)$ & \\
\hline & IIa & $0(0.0 \%)$ & $1(2.4 \%)$ & \\
\hline & $\mathrm{IIb}$ & $4(13.3 \%)$ & $3(7.1 \%)$ & \\
\hline & IIIa & $7(23.3 \%)$ & $9(21.4 \%)$ & \\
\hline & $\mathrm{IIIb}$ & $4(13.3 \%)$ & $8(19.0 \%)$ & \\
\hline & IV & $1(3.3 \%)$ & $0(0.0 \%)$ & \\
\hline \multirow[t]{5}{*}{ Surgery } & Pneumonectomy & $1(3.3 \%)$ & $5(11.9 \%)$ & .736 (Wilcoxon) \\
\hline & Bilobectomy & $3(10.0 \%)$ & $1(2.4 \%)$ & \\
\hline & Lobectomy & $25(83.3 \%)$ & $32(76.2 \%)$ & \\
\hline & Segmentectomy & $0(0.0 \%)$ & $1(2.4 \%)$ & \\
\hline & Wedge resection & $1(3.3 \%)$ & $3(7.1 \%)$ & \\
\hline \multirow[t]{2}{*}{ Postoperative complication } & - & $26(86.7 \%)$ & $37(88.1 \%)$ & $>.999$ (Fisher) \\
\hline & + & $4(13.3 \%)$ & $5(11.9 \%)$ & \\
\hline \multirow[t]{2}{*}{ Second cancer } & - & $26(86.7 \%)$ & $33(78.6 \%)$ & .537 (Fisher) \\
\hline & + & $4(13.3 \%)$ & $9(21.4 \%)$ & \\
\hline \multirow[t]{2}{*}{ Postoperative recurrence } & - & $20(66.7 \%)$ & $16(38.1 \%)$ & $.017\left(\chi^{2}\right)$ \\
\hline & + & $10(33.3 \%)$ & $26(61.9 \%)$ & \\
\hline
\end{tabular}


TABLE 2. Duration from date of surgery until time of tumor recurrence

\begin{tabular}{lc}
\hline Duration $(\mathbf{m o})$ & Number of cases \\
\hline$\leq 3$ & 4 \\
$4-6$ & 6 \\
$7-12$ & 13 \\
$13-24$ & 6 \\
$25-36$ & 4 \\
$\geq 37$ & 3 \\
\hline
\end{tabular}

LCNEC. Of 79 cases, we were unable to evaluate 7 cases due to a lack of information regarding recurrent tumors. Characteristics of the 72 patients examined in this study are shown in Table 1. Of the 72 patients with information on recurrence, 36 did not have recurrent tumors, and in the other 36, recurrent tumors were detected during follow-up examination after surgery.

The 5-year disease-free survival for the 72 patients was $42.7 \%$. Of the 36 patients with recurrent tumors, 23 $(63.9 \%)$ had their first recurrent tumor within 1 year following the operation, and $33(91.7 \%)$ had tumors within 3 years (Table 2). The 5-year overall survival rate for patients with recurrent tumors was $12.5 \%$, which was significantly worse than the rate of patients without recurrence $(88.7 \% ; P<.0001)$.

Sites of recurrence included hilar, mediastinal, or supraclavicular lymph nodes in 18 patients, lungs in 12 patients, brain in 11 patients, bone in 8 patients, and liver in 7 patients. Pleural dissemination was observed in 2 patients. One recurrence each was detected in the adrenal gland, skin, local recurrence, retroperitoneal lymph node, and axillary lymph node (Table 3). Nineteen patients had recurrent tumors with more than 1 site.

We examined the relationship between postoperative adjuvant chemotherapy and tumor recurrence (Table 1). The group that received platinum-based adjuvant chemotherapy had a significantly lower rate of tumor recurrence than the groups with either non-platinum-based adjuvant chemother- apy or no adjuvant chemotherapy $(P=.0168)$. The 5 -year disease-free survival rates of patients with platinum-based adjuvant chemotherapy and patients without were $58.9 \%$ and $33.0 \%$, respectively, and the disease-free survival rates showed that patients with platinum-based adjuvant chemotherapy had significantly better prognoses than patients without $(P=.0444$, Figure 1). Multivariate analyses revealed that platinum-based adjuvant chemotherapy, pathologic stage, and the presence of second cancer are independent prognostic factors (Table 4). Table 5 shows 2 groups divided by propensity score. There were no significant differences on prognosis in propensity score analyses between the group with platinum-based adjuvant chemotherapy and the group without $(P=.14$, Figure 2$)$. Five patients had limited surgery for LCNEC, and of these, 4 patients had poor prognosis ( 3 with recurrence, 1 without recurrence) and only 1 patient with wedge resection survived without recurrence (Table 6).

Postoperatively, of the 36 patients without recurrence, 11 $(30.6 \%)$ patients had metachronous second primary cancers, of which 4 patients had recurrence at more than 1 site (Table 7). Of the 11 patients, only 4 patients underwent postoperative adjuvant chemotherapy. Four patients died due to the second primary cancers.

We examined the treatment and response to platinumbased chemotherapy or radiation therapy for hilar, mediastinal, or supraclavicular lymph node recurrence. In 15 of 18 patients with hilar, mediastinal, or supraclavicular lymph node recurrence, 7 patients $(46.7 \%)$ had either complete or partial response to treatment (Table 3). One patient who had platinum-based chemotherapy (carboplatin + etoposide) and 2 patients who had radiation therapy (42 Gy, 66 Gy) had a complete response, while 4 patients who had radiation therapy (48.5 Gy, $60 \mathrm{~Gy}, 60 \mathrm{~Gy}, 66 \mathrm{~Gy}$ ) showed a partial response, and 1 who had radiation therapy had progressive disease (Table 8). All of the patients having non-platinumbased chemotherapy had progressive disease.

TABLE 3. Sites of recurrent tumors and responses to treatment

\begin{tabular}{|c|c|c|c|c|c|c|}
\hline & \multicolumn{4}{|c|}{ Evaluated } & \multirow[b]{2}{*}{ Not evaluated $(n=22)$} & \multirow[b]{2}{*}{ Total $(n=64)$} \\
\hline & $\mathrm{CR}(\mathrm{n}=4)$ & $\operatorname{PR}(\mathbf{n}=\mathbf{8})$ & $\mathbf{S D}(\mathbf{n}=2)$ & $\operatorname{PD}(\mathbf{n}=28)$ & & \\
\hline $\begin{array}{l}\text { Hilar, mediastinal, or } \\
\text { supraclavicular lymph node }\end{array}$ & 3 & 4 & 0 & 8 & 3 & 18 \\
\hline Lung & 1 & 1 & 0 & 6 & 4 & 12 \\
\hline Brain & 0 & 2 & 2 & 6 & 2 & 12 \\
\hline Bone & 0 & 0 & 0 & 3 & 5 & 8 \\
\hline Liver & 0 & 0 & 0 & 1 & 6 & 7 \\
\hline Dissemination & 0 & 1 & 0 & 1 & 0 & 2 \\
\hline Adrenal gland & 0 & 0 & 0 & 1 & 0 & 1 \\
\hline Skin & 0 & 0 & 0 & 0 & 1 (ope) & 1 \\
\hline Local & 0 & 0 & 0 & 1 & 0 & 1 \\
\hline Retroperitoneal lymph node & 0 & 0 & 0 & 1 & 0 & 1 \\
\hline Axillary lymph node & 0 & 0 & 0 & 0 & 1 (ope) & 1 \\
\hline
\end{tabular}

$C R$, Complete response; ope, operation; $P D$, progressive disease; $P R$, partial response; $S D$, stable disease. 


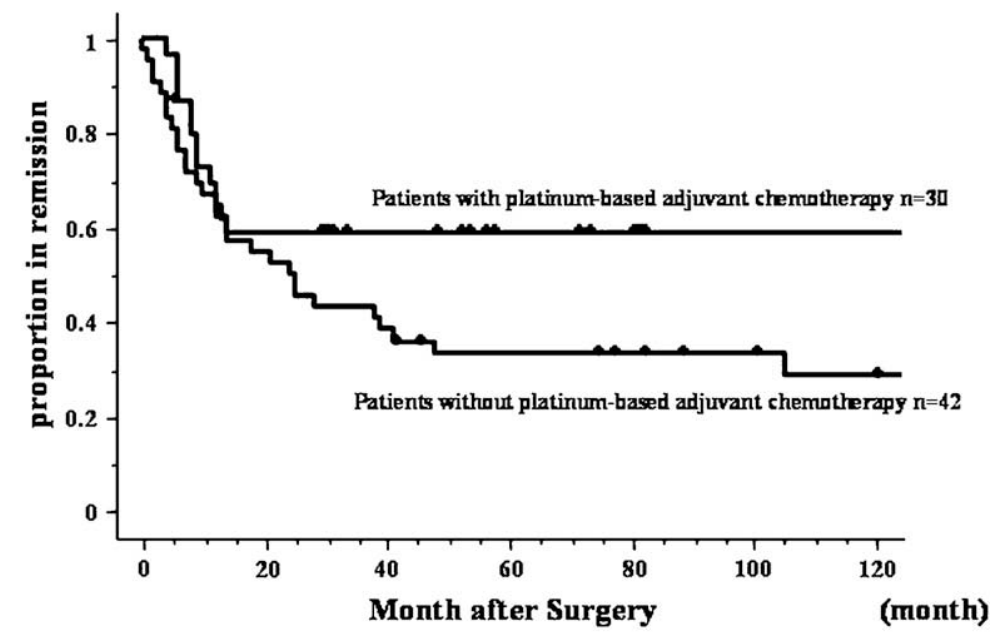

Patients at risk

$\begin{array}{cccccccc}\text { adjuvant } & 30 & 17 & 12 & 7 & 5 & 2 & 2 \\ \text { control } & 42 & 23 & 16 & 12 & 10 & 8 & 6\end{array}$

FIGURE 1. Disease-free survival curves of patients with large-cell neuroendocrine carcinoma with and without platinum-based adjuvant chemotherapy.

In 8 of 12 patients with lung metastases (Table 3 ), only 2 patients showed any response to treatment. One patient using 60-Gy radiation therapy with carboplatin had a complete response, 1 patient using 60-Gy radiation therapy had a partial response, and 6 patients overall showed progressive disease, of which 2 patients received non-platinum-based chemotherapy (Table 8).

In 11 patients, there were 12 instances of brain metastases (Table 3). Of 10 informative cases, only 2 patients had a par- tial response: 1 patient with radiation therapy with $30 \mathrm{~Gy}$ and another with $\gamma$-knife of 20 Gy (Table 8).

\section{DISCUSSION}

Patients with LCNEC generally have poor prognosis. Iyoda and colleagues ${ }^{3}$ reported a $35.5 \%$ 5-year survival rate and a $27.4 \%$ 5-year disease-free survival rate. Other studies have also reported poor prognosis for patients with LCNEC, with 5 -year survival rates ranging from $15 \%$ to $57 \% .^{2,4,13,15-18}$

TABLE 4. The prognostic impact using Cox proportional hazards multivariable regression model

\begin{tabular}{|c|c|c|c|c|c|c|c|}
\hline \multirow[b]{2}{*}{ Factor } & \multirow[b]{2}{*}{ Category } & \multirow[b]{2}{*}{$\mathbf{n}$} & \multirow[b]{2}{*}{ 5-year DFS predicted value from Kaplan-Meier $(\%)$} & \multicolumn{2}{|c|}{ Univariate } & \multicolumn{2}{|c|}{ Multivariate } \\
\hline & & & & HR & $P$ value & HR & $P$ value \\
\hline \multirow[t]{2}{*}{ Adjuvant chemotherapy } & - & 42 & 32.97 & 1.000 & & 1.000 & \\
\hline & + & 30 & 58.93 & 0.500 & .042 & 0.350 & .005 \\
\hline \multirow[t]{2}{*}{ Age $(y)$} & $<65$ & 26 & 55.90 & 1.000 & & 1.000 & \\
\hline & $\geq 65$ & 46 & 35.80 & 1.954 & .050 & 1.951 & .078 \\
\hline \multirow[t]{2}{*}{ Gender } & Male & 66 & 44.06 & 1.000 & & 1.000 & \\
\hline & Female & 6 & 33.33 & 0.877 & .805 & 0.365 & .086 \\
\hline \multirow[t]{2}{*}{ Stage } & $\mathrm{Ia} / \mathrm{Ib}$ & 35 & 57.46 & 1.000 & & 1.000 & \\
\hline & IIa/IIb/IIIa/IIIb/IV & 37 & 29.73 & 2.273 & 011 & 2.176 & .025 \\
\hline \multirow[t]{2}{*}{ Surgery } & Standard & 67 & 45.00 & 1.000 & & 1.000 & \\
\hline & Limited & 5 & 20.00 & 1.530 & .421 & 0.823 & .732 \\
\hline \multirow[t]{2}{*}{ Postoperative complication } & - & 63 & 44.68 & 1.000 & & 1.000 & \\
\hline & + & 9 & 33.33 & 1.701 & .203 & 1.067 & .886 \\
\hline \multirow[t]{2}{*}{ Second cancer } & - & 59 & 35.55 & 1.000 & & 1.000 & \\
\hline & + & 13 & 76.15 & 0.388 & .048 & 0.242 & .008 \\
\hline
\end{tabular}

DFS, Disease-free survival; $H R$, hazard ratio. 
TABLE 5. Patient characteristics using propensity score analyses

\begin{tabular}{|c|c|c|c|c|}
\hline \multirow[b]{2}{*}{ Factor } & \multirow[b]{2}{*}{ Category } & \multicolumn{2}{|c|}{ Adjuvant chemotherapy } & \multirow[b]{2}{*}{$P$ value } \\
\hline & & + & - & \\
\hline Number & & $26(100.0 \%)$ & $26(100.0 \%)$ & \\
\hline \multirow[t]{2}{*}{ Age (y) } & Mean & 64.0 & 64.2 & .715 (Wilcoxon) \\
\hline & Standard deviation & 9.9 & 8.0 & \\
\hline \multirow[t]{2}{*}{ Gender } & Male & $26(100.0 \%)$ & $26(100.0 \%)$ & $>.999$ (Fisher) \\
\hline & Female & $0(0.0 \%)$ & $0(0.0 \%)$ & \\
\hline \multirow[t]{7}{*}{ Pathologic stage } & Ia & $8(30.8 \%)$ & $9(34.6 \%)$ & .807 (Wilcoxon) \\
\hline & $\mathrm{Ib}$ & $6(23.1 \%)$ & $6(23.1 \%)$ & \\
\hline & IIa & $0(0.0 \%)$ & $0(0.0 \%)$ & \\
\hline & $\mathrm{IIb}$ & $3(11.5 \%)$ & $3(11.5 \%)$ & \\
\hline & IIIa & $7(26.9 \%)$ & $5(19.2 \%)$ & \\
\hline & IIIb & $1(3.8 \%)$ & $3(11.5 \%)$ & \\
\hline & IV & $1(3.8 \%)$ & $0(0.0 \%)$ & \\
\hline \multirow[t]{5}{*}{ Surgery } & Pneumonectomy & $1(3.8 \%)$ & $5(19.2 \%)$ & .619 (Wilcoxon) \\
\hline & Bilobectomy & $3(11.5 \%)$ & $0(0.0 \%)$ & \\
\hline & Lobectomy & $21(80.8 \%)$ & $20(76.9 \%)$ & \\
\hline & Segmentectomy & $0(0.0 \%)$ & $0(0.0 \%)$ & \\
\hline & Wedge resection & $1(3.8 \%)$ & $1(3.8 \%)$ & \\
\hline \multirow[t]{2}{*}{ Postoperative complication } & - & $22(84.6 \%)$ & $24(92.3 \%)$ & .668 (Fisher) \\
\hline & + & $4(15.4 \%)$ & $2(7.7 \%)$ & \\
\hline \multirow[t]{2}{*}{ Second cancer } & - & $22(84.6 \%)$ & $21(80.8 \%)$ & $>.999$ (Fisher) \\
\hline & + & $4(15.4 \%)$ & $5(19.2 \%)$ & \\
\hline
\end{tabular}

Even those patients with LCNEC at pathologic stage I show poor prognosis, with 5 -year survival rates of $27 \%$ to $67 \%$. Therefore, surgery alone may not be sufficient for treating LCNEC. In 2001, Iyoda and colleauges ${ }^{10}$ revealed that adjuvant chemotherapy was effective for treating patients with LCNEC. ${ }^{10}$ Rossi and associates ${ }^{13}$ in 2005 and Iyoda and colleagues $^{12}$ in 2006 showed that patients receiving adjuvant chemotherapy, especially cisplatin+etoposide, had good prog- nosis after complete surgical resection and that adjuvant chemotherapy was promising for patients with LCNEC.

In this study, we determined that platinum-based adjuvant chemotherapy for LCNEC patients following surgery was significant in preventing recurrence. Although many patients with advanced-stage LCNEC were included in our study, we had comparatively better prognoses than other reports, likely due to the inclusion of patients with LCNEC

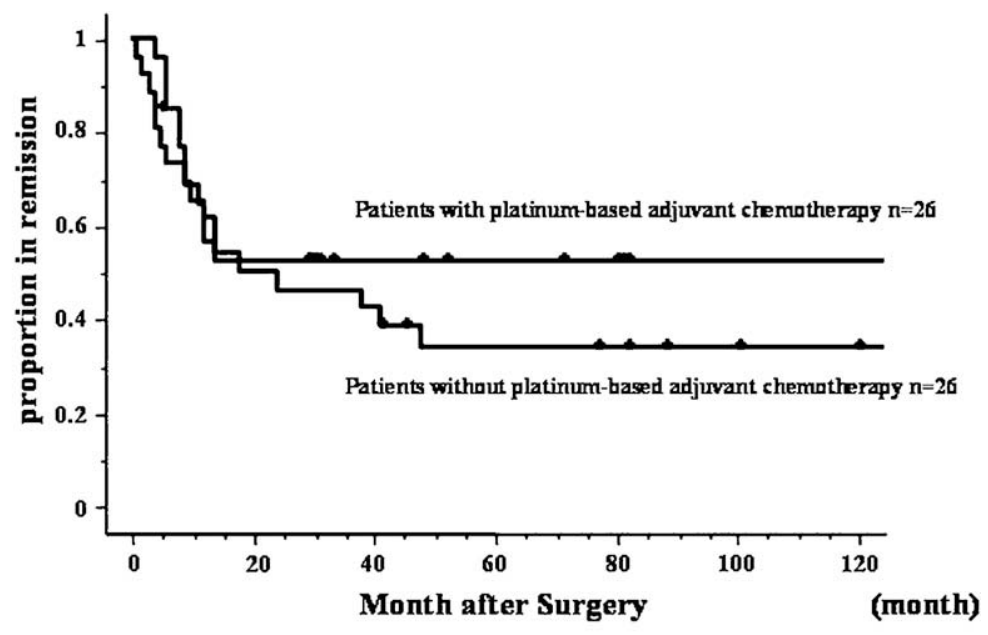

Patients at risk

$\begin{array}{cccccccc}\text { adjuvant } & 26 & 13 & 8 & 6 & 5 & 2 & 2 \\ \text { control } & 26 & 13 & 11 & 7 & 6 & 4 & 3\end{array}$

FIGURE 2. Disease-free survival curves of matching cases for propensity score analyses. 
TABLE 6. Patients with limited resection of the large-cell neuroendocrine carcinoma tumor

\begin{tabular}{lllccc}
\hline Age $(\mathbf{y})$ & Gender & Surgical procedure & Tumor size $(\mathbf{c m})$ & N, M & Status \\
\hline 75 & Female & Wedge resection & 2.0 & N0M0 & Deceased (46 mo) \\
75 & Male & Wedge resection & 1.7 & N0M0 & Deceased (2 mo) \\
68 & Male & Wedge resection & 2.0 & N0M0 & Alive (46 mo) \\
69 & Male & Segmentectomy & 1.4 & N0M0 & Deceased (28 mo) \\
67 & Male & Wedge resection & 4.4 & N0M0 & Deceased (11 mo) \\
\hline
\end{tabular}

$N$, Lymph node metastasis; $M$, distant metastasis.

treated with platinum-based adjuvant chemotherapy. Moreover, multivariate analyses revealed that platinum-based adjuvant chemotherapy was a significant prognostic factor in patients with LCNEC, although propensity score analyses could not show those. In this study, platinum-based adjuvant chemotherapy was promising for patients with LCNEC.

Previous reports have found that LCNEC tumors show good response to chemotherapy. ${ }^{11}$ However, there have been few reports on treatment for patients with LCNEC and limited information on sites of recurrent tumors. Moreover, many clinicians could not resolve the kinds of treatment performed for patients with recurrent tumors of LCNEC, and the treatments were not unified. Therefore, a limitation of this study was due to results conducted from this retrospective analysis. However, we were able to glean much information regarding the frequent sites of recurrent tumors and responses to actual treatment methods used. Many patients with recurrent tumors of LCNEC had very poor prognosis, but other patients showed good responses to treatment, especially treatment with platinumbased chemotherapy, radiation therapy, and the combination of the 2. Thus platinum-based chemotherapy or radiation

TABLE 7. Postoperative second primary cancer in 36 patients without recurrence

\begin{tabular}{|c|c|c|c|}
\hline Age (y) & Gender & Postoperative second cancer & Status \\
\hline 55 & Male & Gastric cancer & Alive \\
\hline 56 & Male & Rectal cancer & Alive \\
\hline 58 & Male & Gastric cancer & Alive \\
\hline 66 & Male & $\begin{array}{l}\text { Esophageal cancer, } \\
\text { pharyngeal cancer, } \\
\text { urinary bladder cancer }\end{array}$ & Alive \\
\hline 67 & Male & Lung cancer & $\begin{array}{l}\text { Died from } \\
\text { second cancer }\end{array}$ \\
\hline 70 & Male & Esophageal cancer & $\begin{array}{l}\text { Died from } \\
\text { second cancer }\end{array}$ \\
\hline 70 & Male & $\begin{array}{l}\text { Pharyngeal cancer, } \\
\text { gastric cancer }\end{array}$ & $\begin{array}{l}\text { Died from } \\
\text { second cancer }\end{array}$ \\
\hline 71 & Male & $\begin{array}{l}\text { Gastric cancer, } \\
\text { lung cancer }\end{array}$ & Alive \\
\hline 72 & Male & Cholangiocarcinoma & Alive \\
\hline 73 & Male & $\begin{array}{l}\text { Vocal cord cancer, } \\
\text { esophageal cancer }\end{array}$ & $\begin{array}{l}\text { Died from } \\
\text { second cancer }\end{array}$ \\
\hline 74 & Male & Lung cancer & Alive \\
\hline
\end{tabular}

therapy appears promising as effective treatments for LCNEC recurrent tumors.

In examining the follow-ups of LCNEC patients, we found that most recurrent tumors occurred within 3 years after surgery and that patients with LCNEC showed frequent brain metastases. Metastatic brain tumors of LCNEC are not always responsive to treatment. Therefore, we should use brain magnetic resonance imaging to carefully follow patients after resection of LCNEC tumors. Gamma knife treatment is useful for metastatic brain tumors, ${ }^{19}$ and in this study, of 2 patients treated by gamma knife, 1 patient had a partial response. Treatment of brain metastases in patients with LCNEC is very difficult, but gamma knife treatment may be a useful strategy for metastatic brain tumors of LCNEC.

TABLE 8. Treatment and response for hilar, mediastinal, or supraclavicular lymph node recurrence, lung metastases, and brain metastases

\begin{tabular}{|c|c|c|c|c|c|c|}
\hline & \multicolumn{4}{|c|}{ Evaluated } & \multirow[b]{2}{*}{ Not evaluated } & \multirow[b]{2}{*}{ Total } \\
\hline & $\mathbf{C R}$ & PR & SD & PD & & \\
\hline $\mathrm{LN}$ recurrence & 3 & 4 & 0 & 8 & 3 & 18 \\
\hline PB chemotherapy & 1 & 0 & 0 & 0 & 0 & 1 \\
\hline NPB chemotherapy & 0 & 0 & 0 & 3 & 0 & 3 \\
\hline Radiation therapy & 2 & 4 & 0 & 1 & 0 & 7 \\
\hline Chemoradiation & 0 & 0 & 0 & 0 & 1 & 1 \\
\hline Conservative & 0 & 0 & 0 & 4 & 1 & 5 \\
\hline Unknown & 0 & 0 & 0 & 0 & 1 & 1 \\
\hline Lung metastases & 1 & 1 & 0 & 6 & 4 & 12 \\
\hline PB chemotherapy & 0 & 0 & 0 & 1 & 0 & 1 \\
\hline NPB chemotherapy & 0 & 0 & 0 & 2 & 0 & 2 \\
\hline Radiation therapy & 0 & 1 & 0 & 0 & 0 & 1 \\
\hline Chemoradiation & 1 & 0 & 0 & 0 & 0 & 1 \\
\hline NKT therapy & 0 & 0 & 0 & 1 & 0 & 1 \\
\hline Conservative & 0 & 0 & 0 & 2 & 1 & 3 \\
\hline Unknown & 0 & 0 & 0 & 0 & 3 & 3 \\
\hline Brain metastases & 0 & 2 & 2 & 6 & 2 & 12 \\
\hline Radiation therapy & 0 & 1 & 1 & 0 & 0 & 2 \\
\hline$\gamma$-knife & 0 & 1 & 1 & 0 & 1 & 3 \\
\hline Operation + radiation therapy & 0 & 0 & 0 & 3 & 0 & 3 \\
\hline Chemoradiation & 0 & 0 & 0 & 1 & 0 & 1 \\
\hline Operation & 0 & 0 & 0 & 1 & 0 & 1 \\
\hline Conservative & 0 & 0 & 0 & 1 & 0 & 1 \\
\hline Unknown & 0 & 0 & 0 & 0 & 1 & 1 \\
\hline
\end{tabular}


Natural killer $\mathrm{T}$ cells show strong antitumor activity against various malignant tumors both in vitro and in vivo, producing a high level of cytokines. Treatment using natural killer $\mathrm{T}$ cells appears promising as an effective method in lung cancer patients. ${ }^{20}$ In this study, the use of natural killer $\mathrm{T}$ cells was performed in only 1 patient with pulmonary metastasis, and the treatment effectiveness was not able to be determined.

Recently, some clinicians have performed limited resection rather than standard lobectomy for small non-small cell lung cancers, especially adenocarcinoma. ${ }^{21}$ However, our study showed that patients with limited resection of primary LCNEC tumors frequently experienced recurrence; therefore, if possible, standard operation should be performed, even with small LCNEC tumors.

Although it is important to check for LCNEC tumor recurrence, we must also be aware of new cancer lesions, including those at other sites. Our results showed a high rate of postoperative secondary cancers following surgery for LCNEC tumors. The incidence of second primary digestive cancer after resection of lung cancer has been reported as $1 \%$ to $2 \%{ }^{22}$ The number of patients successfully treated for their initial non-small cell lung carcinoma and at risk of developing a second non-small cell lung carcinoma has been reported as approximately $1 \%$ to $2 \% \cdot{ }^{23,24}$ From this point of view, our results revealed a very high rate for developing a second primary cancer in patients with LCNEC, including 4 patients who had more than 1 tumor. As only 4 of 11 patients with a second primary cancer had adjuvant chemotherapy, we cannot necessarily consider that the second primary cancers were caused by adjuvant chemotherapy. ${ }^{25}$ Even if 36 of 72 patients did not show LCNEC tumor recurrences, 11 patients had a metachronous second primary cancer, and 4 of 11 patients died due to their second primary cancer. Although LCNEC tumors show aggressive behavior as a matter of course, this may be one reason that patients with LCNEC have poor prognosis.

In conclusion, although it has been reported that LCNEC patients have frequent recurrent tumors and very poor prognoses, we determined that platinum-based adjuvant chemotherapy after surgery significantly prevents recurrence and that recurrent tumors may also be responsive to platinum-based chemotherapy, radiation therapy, or the combination of the 2 . In addition, if possible, limited resection of LCNEC tumors should not be performed due to the poor outcome. Frequent areas of recurrence include the thoracic lymph nodes, lung, brain, bone, and liver, and it is important to look for recurrence within the first 3 years after surgical resection, as well as evidence of postoperative secondary cancers. The results of this study are very important, not only to consider treatment and follow-up methods of patients with LCNEC, but also to understand the biologic behavior and development of LCNEC.

\section{References}

1. Travis WD, Colby TV, Corrin B, Shimosato Y, Brambilla E, eds. Histological typing of lung and pleural tumours. World Health Organization International Histological Classification of Tumors, XIII. 3rd ed. Berlin/Heidelberg: Springer-Verlag; 1999.

2. Iyoda A, Hiroshima K, Nakatani Y, Fujisawa T. Pulmonary large cell neuroendocrine carcinoma: its place in the spectrum of pulmonary carcinoma. Ann Thorac Surg. 2007;84:702-7.

3. Iyoda A, Hiroshima K, Toyozaki T, Haga Y, Fujisawa T, Ohwada H. Clinical characterization of pulmonary large cell neuroendocrine carcinoma and large cell carcinoma with neuroendocrine morphology. Cancer. 2001;91:1992-2000.

4. Asamura H, Kameya T, Matsuno Y, Noguchi M, Tada H, Ishikawa Y, et al. Neuroendocrine neoplasms of the lung: a prognostic spectrum. JClin Oncol. 2006;24:70-6.

5. Iyoda A, Hiroshima K, Moriya Y, Mizobuchi T, Otsuji M, Sekine Y, et al. Pulmonary large cell neuroendocrine carcinoma demonstrates high proliferative activity. Ann Thorac Surg. 2004;77:1891-5.

6. Iyoda A, Hiroshima K, Baba M, Saitoh Y, Ohwada H, Fujisawa T. Pulmonary large cell carcinomas with neuroendocrine features are high-grade neuroendocrine tumors. Ann Thorac Surg. 2002;73:1049-54.

7. Onuki N, Wistuba II, Travis WD, Virmani AK, Yashima K, Brambilla E, et al. Genetic changes in the spectrum of neuroendocrine lung tumors. Cancer. 1999; 85:600-7.

8. Jones MH, Virtanen C, Honjoh D, Miyoshi T, Satoh Y, Okumura S, et al. Two prognostically significant subtypes of high-grade lung neuroendocrine tumours independent of small-cell and large-cell neuroendocrine carcinomas identified by gene expression profiles. Lancet. 2004;363:775-81.

9. Hiroshima K, Iyoda A, Shibuya K, Haga Y, Toyozaki T, Iizasa T, et al. Genetic alterations in early-stage pulmonary large cell neuroendocrine carcinoma. Cancer. 2004;100:1190-8.

10. Iyoda A, Hiroshima K, Toyozaki T, Haga Y, Baba M, Fujisawa T, et al. Adjuvant chemotherapy for large cell carcinoma with neuroendocrine features. Cancer. 2001;92:1108-12.

11. Yamazaki S, Sekine I, Matsuno Y, Takei H, Yamamoto N, Kunitoh H, et al. Clinical responses of large cell neuroendocrine carcinoma of the lung to cisplatinbased chemotherapy. Lung Cancer. 2005;49:217-23.

12. Iyoda A, Hiroshima K, Moriya Y, Takiguchi Y, Sekine Y, Shibuya K, et al. Prospective study of adjuvant chemotherapy for pulmonary large cell neuroendocrine carcinoma. Ann Thorac Surg. 2006;82:1802-7.

13. Rossi G, Cavazza A, Marchioni A, Longo L, Migaldi M, Sartori G, et al. Role of chemotherapy and the receptor tyrosine kinases KIT, PDGFRalpha, PDGFRbeta, and Met in large-cell neuroendocrine carcinoma of the lung. J Clin Oncol. 2005; 23:8774-85.

14. Therasse P, Arbuck SG, Eisenhauer EA, Wanders J, Kaplan RS, Rubinstein L, et al. New guidelines to evaluate the response to treatment in solid tumors. European Organization for Research and Treatment of Cancer, National Cancer Institute of the United States, National Cancer Institute of Canada. J Natl Cancer Inst. 2000;92:205-16.

15. Travis WD, Rush W, Flieder DB, Falk R, Fleming MV, Gal AA, et al. Survival analysis of 200 pulmonary neuroendocrine tumors with clarification of criteria for atypical carcinoid and its separation from typical carcinoid. Am J Surg Pathol. 1998;22:934-44.

16. Paci M, Cavazza A, Annessi V, Putrino I, Ferreri G, De Franco S, et al. Large cell neuroendocrine carcinoma of the lung: a 10-year clinicopathologic retrospective study. Ann Thorac Surg. 2004;77:1163-7.

17. Battafarano RJ, Fernandez FG, Ritter J, Meyers BF, Guthrie TJ, Cooper JD, et al. Large cell neuroendocrine carcinoma: an aggressive form of non-small cell lung cancer. J Thorac Cardiovasc Surg. 2005;130:166-72.

18. Skuladottir H, Hirsch FR, Hansen HH, Olsen JH. Pulmonary neuroendocrine tumors: incidence and prognosis of histological subtypes. A population-based study in Denmark. Lung Cancer. 2002;37:127-35.

19. Mehta MP, Tsao MN, Whelan TJ, Morris DE, Hayman JA, Flickinger JC, et al. The American Society for Therapeutic Radiology and Oncology (ASTRO) evidence-based review of the role of radiosurgery for brain metastases. Int J Radiat Oncol Biol Phys. 2005;63:37-46.

20. Ishikawa A, Motohashi S, Ishikawa E, Fuchida H, Higashino K, Otsuji M, et al. A phase I study of alpha-galactosylceramide (KRN7000)-pulsed dendritic cells in patients with advanced and recurrent non-small cell lung cancer. Clin Cancer Res. 2005;11:1910-7.

21. Okada M, Koike T, Higashiyama M, Yamato Y, Kodama K, Tsubota N. Radical sublobar resection for small-sized non-small cell lung cancer: a multicenter study. J Thorac Cardiovasc Surg. 2006;132:769-75. 
22. Kamiyama H, Ikeya T, Suda K, Murai K, Aoyama K, Hoshi E. Second primary digestive cancer after resection of lung cancer. Surg Today. 2004;34:577-80.

23. Battafarano RJ, Force SD, Meyers BF, Bell J, Guthrie TJ, Cooper JD, et al. Benefits of resection for metachronous lung cancer. J Thorac Cardiovasc Surg. 2004; 127:836-42.
24. Johnson BE. Second lung cancers in patients after treatment for an initial lung cancer. J Natl Cancer Inst. 1998;90:1335-45.

25. van den Belt-Dusebout AW, de Wit R, Gietema JA, Horenblas S, Louwman MW, Ribot JG, et al. Treatment-specific risks of second malignancies and cardiovascular disease in 5-year survivors of testicular cancer. J Clin Oncol. 2007;25:4370-8.

Access to The Journal of Thoracic and Cardiovascular Surgery Online is reserved for print subscribers!

Full-text access to The Journal of Thoracic and Cardiovascular Surgery Online is available for all print subscribers. To activate your individual online subscription, please visit The Journal of Thoracic and Cardiovascular Surgery Online, point your browser to http://www.mosby.com/jtcvs, follow the prompts to activate your online access, and follow the instructions. To activate your account, you will need your subscriber account number, which you can find on your mailing label (note: the number of digits in your subscriber account number varies from 6 to 10 ). See the example below in which the subscriber account number has been circled:

\section{Sample mailing label}

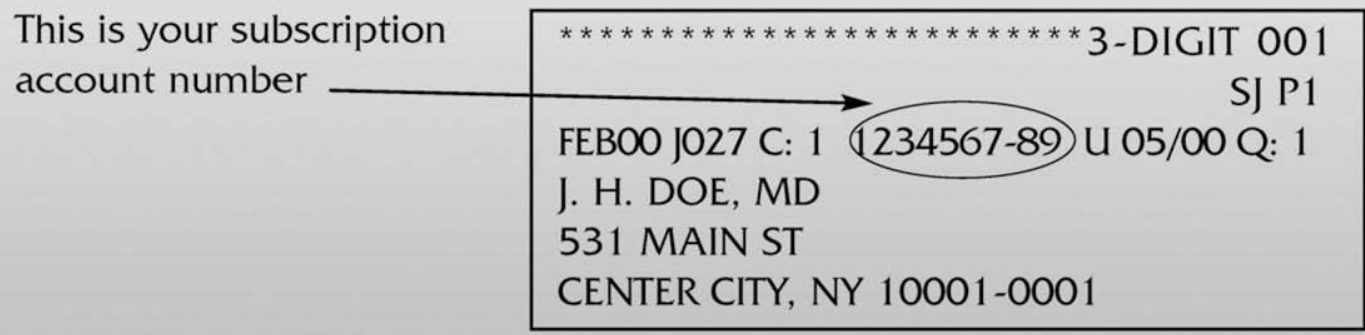

Personal subscriptions to The Journal of Thoracic and Cardiovascular Surgery Online are for individual use only and may not be transferred. Use of The Journal of Thoracic and Cardiovascular Surgery Online is subject to agreement to the terms and conditions as indicated online. 